\title{
COMMUNICATION COMPETENCES OF STUDENTS WITH SPECIAL EDUCATION NEEDS AND TEACHERS AS A "TOOL" ON THE WAY TO INCLUSION
}

\author{
Iwona Konieczna \\ The Maria Grzegorzewska University Warsaw (POLAND)
}

\begin{abstract}
Currently there is a tendency to describe communication competence as a kind of "multidimensional composition" which include various specific competences, not only in the sphere of language, and allows for practical implementation of various types of speech acts., The child should be able to confront its existing competences when entering into the school space. The child should be also able to participate in new and various situations which will help with a development and improvement in order to receive satisfactory level (from the individual's perspective) of functioning in different communication relationships aside from environment of home and school.

The article will focus on communication competences of students with special educational needs, especially emphasizing on "communication match of teachers" to students' abilities, which is necessary in building a common conversation exchange.
\end{abstract}

Keywords: student with special educational needs, teacher, communication competence, inclusion.

\section{INTRODUCTION}

The contemporary school is still looking for ways to educate and bring up diverse groups of students. The implementation of the inclusion education paradigm in pedagogical activities turns into a new skill, method, and new system.

Inclusive education is an ongoing process aimed to offer high quality education to everyone and to respect the diversity, needs and abilities, characteristics and expectations of students with different needs.

Special educational needs particularly refer to the group of students who cannot meet the requirements of the generally applicable educational program. They have much more learning difficulties than their peers. They are able to continue their education, but they need pedagogical help focused to their needs, possibilities and limitations. They should be taught by specialized staff in appropriate base conditions, taking into account different organizational solutions (Bogdanowicz 1995: 216).

Planning the didactic process for students with special educational needs, including the social learning environment, focuses on adapting educational offers to the specificity of students' development at a given stage of development (Brzezińska 2008).

Assistance to a diverse group of students with special educational needs should take into account the moment of development along with the normative emotions for each student, cognitive readiness, mode of action and motivation to change, ways of communicating their needs, as well as the features of the environment in which the student operates.

Communication competence and its components are necessary in every situation between at least two people. Communication competences have a special significance when a child with special educational needs enters into a complicated relationship between people with different communication resources and social status. It is then necessary for the student to use the appropriate repertoire of skills and benefit from a specific resource of words that will allow him to make satisfactory contacts. In order for this to happen, the child should also understand the symbolism of certain formulations and terms, receive and at the same time combine verbal messages with desirable and consistent nonverbal messages. It is also important that the student reflect on the readability of his message, apply transparency in his own speech and analyze consistency from the point of view of its recipient. What's more important, it seems that the student has the ability to correct in the message given by the message illegible to the recipient or incorrect and properly tried to "match" to his interlocutor. 
The place where the child has the opportunity to establish relationships with other people who have different communication resources and experiences, as well as opportunities to improve competences related to communication with others is a school where teachers (their knowledge and skills and attitude) set the path for common and effective communication.

\section{METHODOLOGY}

The aim of the research was to recognize the range of communication competences of students with special educational needs in school situations, as well as to observe in "here and now" activities undertaken by teachers which allowed to create conditions in order to meet educational needs. The main research problem refers to the range of competences revealed by students with special communication needs in school situations and what actions should teachers take to create conditions aimed to meet individual educational needs.

The research was qualitative and was carried out in accordance with the adopted methodology of grounded theory methodology (G., B. Glaser, A., L. Strauss, 1967). The main technique for gathering empirical material was explicit, participatory and continuous observation. I assumed that it would allow to learn the range of communication competences of observed students with special educational needs, determine their individual needs and possibilities during educational classes (Polish language education, mathematics education, art education, music education, physical education classes, computer classes, English language). I assumed also that it will present the teachers ways of creating conditions which will meet educational needs.

The research group consisted of 15 children with a certificate of the need for special education, who are in the first stage of education (early school education). All students were students in public classes. Observations were conducted from mid-September 2018 to January 2019. The basic criterion was having a certificate about the need for special education.

\section{RESULTS}

The collected empirical material allowed for the analysis of the range of communication competences, allowing to determine the needs and possibilities of the discussed group of students during educational classes, and outlines the methods of teachers' activities in creating conditions for meeting the educational needs of students in an integration institution.

Observations of school situations with the participation of students with special educational needs and teachers have shown that communication competences can be described as a developed category of specific skills that not only fall within the sphere of language, but significantly extend beyond its area, allowing specific entities to send and receive different types of messages.

The basic components that capture the educational situation in terms of communication include: (1) the existence of two communicating entities: teacher - student; (2) language communication (when this element does not occur, one cannot speak about the didactic situation); (3) the teacher as the organizer of the communication process, which affects students, and (4) the didactic situation, which includes all activities, both verbal and non-verbal.

The message in interpersonal communication includes three main elements: verbal communication, which refers to the content of the speech, non-verbal elements such as: the sound of the voice (timbre, intonation, speaking speed, accent and paralanguage) and non-verbal communication, which includes facial expressions, attitude, gestures, distance from individual interlocutors and communication by touch, which is important for students with Asperger's syndrome.

Teachers in contact with surveyed students reveal awareness of the function of language in communication that can help them work with students. In addition, both student and teacher activities can be distinguished in the communication process during classes. Student activities include: (1) active participation; (2) asking questions; (3) answering questions; (4) communicating with others during classes; (5) performing tasks. The teacher's activities include: (1) presenting the content in a clear way; (2) asking questions; (3) providing instructions; (3) providing feedback; (4) assessment.

Undoubtedly, certain substantive content is transmitted to the students by the teacher through a verbal channel, while non-verbal messages supplement the verbal message. Emphasizing individual phrases, voice modulation, emotional reference to the topic - those are just some of the elements that allow the 
teacher to present specific content and motivate children to express themselves and establish communication relationships.

Observations of educational situations have shown that, by attempting to address a teacher's statements, students may reveal various strategies that can help them. One can indicate here, among others, the coherence of opinions expressed, judgments with given facts, and non-linguistic properties that occur during the speech, including, e.g., speech rate, intonation, accent, facial expressions, facial expressions, gestures, and voice color.

\section{CONCLUSIONS}

Developing communication skills of students with special educational needs should take place simultaneously in many areas, taking into account: (1) the personal significance that students attribute to knowledge by adopting techniques and strategies tailored to the individual student's capabilities. (2) using the language in terms of a tool that allows to integrate content from various fields of scientific cognition. (3) strategies in relation to the form of classes (resignation from the frontal form, in favor of working in small groups) which will allow students with different communication competences to better understand the discussed content. (4) the use of methods based on mutual cooperation at work, where students with special educational needs will have the opportunity to present individual reception of content, which may generate their greater activity during classes. (5) managing the learning process in such a way that students can function in the social space as satisfactorily as possible by performing specific roles.

Developing teachers' communication competences requires an approach from them, in which they will try to "empower students", reflect on their real needs and improvements, mutual relations. The interpretative dimension of the teacher's communication competences becomes the basis for building and implementing mutual relations of students with special educational needs.

Despite many permanent elements, educational situations are unique and open due to the participation of diverse groups of students with special educational needs. When interacting with students with special educational needs, the teacher should be open to the multiple meanings of communication situations in a diverse group. The purpose of such interaction according to R. Kwaśnica (1994: 10-12) teacher student, student - teacher is the intention of agreement, which is expressed in the quest to agree on a common interpretation of the surrounding world.

The quality of specific messages addressed to students largely depends on the attitude and motivation of the teacher. A traditional teacher will prefer the transfer of knowledge itself, while a modern teacher will primarily focus on his relationships with students and their appropriate level of communication. This is a characteristic way of the communication model in education, providing students not only the opportunity to dialogue with the teacher, other adults or peers, but also with themselves. This seems to be the most optimal approach on the road to inclusions. One should not forget about the implementation of the assumptions arising from the education system.

The process of inclusion of a student with special educational needs is conditioned by many factors. One of the key seems to be the ability to establish correct relationships, which is conditioned by the communication competences of the participants of the interaction. In an educational situation, this means that both the teacher and students must have specific communication skills. Therefore, it should be assumed that communication competences can become an inclusion tool only if both the teacher and the student are able to communicate effectively. This awareness is a prerequisite for effective communication, which is the foundation of inclusions. Developing communication skills for students with special communication needs is largely dependent on the competence of teachers. Similarly, as the quality of the education process is highly dependent on teachers; their qualifications and communication competences (Strykowski 2003: 28).

It is worth to pose key problems in relation to the discussed issue: Are the Polish student education system and teacher education system sufficient to develop their communication competences? What actions do educational institutions take to improve the communication skills of teachers at work with students with special educational needs? Do and how are the communication possibilities of students with special educational needs identified in institutions, and how do teachers support the development of students' communication competences, especially students with special educational needs? 


\section{REFERENCES}

[1] A. Brzezińska, „Czym może być aktywne uczestnictwo ucznia i nauczyciela?” in Uczyć inaczej (G. Lutomski, eds.), pp. 31 - 40, Poznań: Wydawnictwo Fundacji Humaniora, 1994.

[2] A. I. Brzezińska, „Nauczyciel jako organizator społecznego środowiska uczenia się” in Rozwijanie zdolności uczenia się. Wybrane konteksty i problemy. (A. Filipiak eds.), pp. 35 - 50, Bydgoszcz: Wydawnictwo Uniwersytetu Kazimierza Wielkiego UKW, 2008.

[3] A. I. Brzezińska, S. Jabłoński, B. Ziółkowska, Specyficzne i specjalne potrzeby edukacyjne, Edukacja, 2(127), pp. 37-52, 2014.

[4] A. Mehrabian, An Analysis of Personality Theories, Prentice-Hall, Englewood Cliffs, New Jersey, 1968.

[5] B. Makles, Komunikacja jako problem badawczy dydaktyki in Współczesne kierunki modernizacji dydaktyki (J. Półturzycki, E. Wesołowska eds), pp. 74 - 81, Toruń: Uniwersytet Mikołaja Kopernika, 1993.

[6] B. Papuda - Dolińska, Realizacja koncepcji inkluzji edukacyjnej w szkołach Planu Jenajskiego doświadczenia holenderskie in Podmiotowość w edukacji wobec odmienności kulturowych oraz społecznych zróżnicowań (N. Starnik, A. Zduniak eds.), pp. 427 - 439, Poznań: Wydawnictwo Wyższej Szkoły Bezpieczeństwa, 2012.

[7] CH. Woodruffe,. Ośrodki oceny i rozwoju. Narzędzia analizy $i$ doskonalenia kompetencji pracowników, Kraków: Wydawnictwo Oficyny Ekonomiczna, 2003.

[8] D. Hymes, Socjolingwistyka i etnografia mówienia in Język i społeczeństwo (M. Głowiński eds), pp. 41 - 82, Warszawa: Czytelnik, 1980.

[9] G. Filipowicz, Zarządzanie kompetencjami zawodowymi, Warszawa: PWE, 2004.

[10] G. W. Shugar, M. Smoczyńska (eds) Badania nad rozwojem języka dziecka, Warszawa: PWN, 1980.

[11] H. Kwiatkowska, Źródła inspiracji nowego myślenia o edukacji nauczycielskiej in Źródła inspiracji nowego myślenia o edukacji nauczycielskiej (H. Kwiatkowska, T. Lewowicki eds.) pp. 41 - 57, Warszawa: Wydawnictwo Wyższej Szkoły Pedagogicznej ZNP Polskiego Towarzystwa Pedagogicznego, 1997.

[12] J. Malinowska, Edukacyjny kontekst kompetencji komunikacyjnych nauczyciela in Kompetencje nauczyciela. Stan, potrzeby i kierunki zmian (E. Kozioł, E. Kobyłecka eds.) pp. 101 - 107, Zielona Góra: Oficyna wydawnicza UZ, 2002.

[13] K. Hurrelmann, Struktura społeczna a rozwój osobowości. Wprowadzenie do teorii socjalizacji, Poznań: Wydawnictwa UAM, 1994.

[14] K. Stech, Kompetencje zawodowe nauczyciela - spojrzenie na problem in Kompetencje nauczyciela - wychowawcy (K. Ferenz, E. Kozioł eds.), pp. 11 - 20, Zielona Góra: Redakcja Wydawnictw Humanistyczno - Społecznych Uniwersytetu Zielonogórskiego, 2002.

[15] M. Bogdanowicz „Uczeń o specjalnych potrzebach edukacyjnych” „Psychologia Wychowawcza”, nr 3, pp. 216-223, 1995.

[16] M. Czerepaniak - Walczak, Aspekty i źródła profesjonalnej refleksji nauczyciela, Toruń: Wydawnictwo Edytor, 1997.

[17] M. Grochowalska, Gestykulacja i mowa, Kraków: Wydawnictwo Naukowe Akademii Pedagogicznej, 2002.

[18] M. Kielar Turska, Orientacja dorosłych w kompetencjach komunikacyjnych dziecka in Polska terminologia logopedyczna (J. Ożdzyński eds.), pp. 9 - 20, Kraków: Wydawnictwo Secesja, 1994.

[19] M. Sikorski, „Kompetencje komunikacyjne nauczycieli” Colloquium wydziału nauk humanistycznych i społecznych vol. II. pp. 155 - 172, 2010.

[20] Rozporządzenie Ministra Edukacji Narodowej z dnia 09 sierpnia 2017 r. w sprawie zasad udzielania i organizacji pomocy psychologiczno-pedagogicznej w publicznych przedszkolach, szkołach i placówkach (Dz. U. z 2017 poz.1591). 
[21] R. Kwaśnica, Wprowadzenie do myślenia o wspomaganiu nauczycieli w rozwoju, Wrocław: Wrocławska Oficyna Nauczycielska Wojewódzkiego Ośrodka Metodycznego, 1994.

[22] R. Wawrzyniak, Kompetencje komunikacyjne nauczyciela w aspekcie etycznym in Rola wartości $i$ powinności moralnych w kształtowaniu świadomości profesjonalnej nauczyciela (A. Tchórzewski eds.), pp. 175 - 181, Bydgoszcz: Wydawnictwo Uczelniane WSP, 1994.

[23] S. P. Morreale, B. H. Spitzberg, J. K. Barge, Komunikacja między ludźmi. Motywacja, wiedza, umiejętności, Warszawa: Wydawnictwo Naukowe PWN, 2007.

[24] T. Pearson, Nauczyciel. Teoria i praktyka w kształceniu nauczycieli, Warszawa: WSPI, 1994.

[25] T. Rittel, Podstawy lingwistyki edukacyjnej, Kraków: Wydawnictwo Naukowe WSP, 1994.

[26] W. Okoń, Nowy Słownik Pedagogiczny, Warszawa: Wydawnictwo Akademickie „Żak”, 1996.

[27] W. Strykowski, J. Strykowska, J. Pielachowski, Kompetencje nauczyciela szkoły współczesnej, Poznań: Wydawnictwo eMPi, 2003

[28] Z. Aleksander, „Komunikacja”, in Encyklopedia pedagogiczna XXI wieku, vol. 2, (T. Pilch eds.), Warszawa, 2006.

[29] Z. Mysłakowski, Co to jest talent pedagogiczny? in Osobowość nauczyciela (W. Okoń eds.), pp. 57 - 68, Warszawa: Państwowe Zakłady Wydawnictw Szkolnych, 1962. 